\title{
Coronary artery aneurysm presenting as STEMI
}

\author{
Anandbir Bath, ${ }^{\oplus 1}$ Faizan Shaikh, ${ }^{1}$ Jagadeesh K Kalavakunta ${ }^{2}$
}

'Department of Internal Medicine, Western Michigan University Homer Stryker MD School of Medicine, Kalamazoo, Michigan, USA ${ }^{2}$ Department of Cardiology, Ascension Borgess Medical Center, Kalamazoo, Michigan, USA

\section{Correspondence to Dr Anandbir Bath bathanand@gmail.com}

Accepted 6 June 2019

\section{Check for updates}

(C) BMJ Publishing Group Limited 2019. No commercial re-use. See rights and permissions. Published by BMJ.

To cite: Bath $A$, Shaikh $F_{\text {, }}$ Kalavakunta JK. BMJ Case Rep 2019;12:e231013. doi:10.1136/bcr-2019231013

\section{DESCRIPTION}

A 75-year-old man presenting with sudden onset angina was found to have inferior wall ST elevation myocardial infarction (figure 1). He was emergently scheduled for cardiac catheterisation. Coronary angiography revealed aneurysmal dilatation of distal right coronary artery (RCA) with 100\% occlusion from thrombosis at the aneurysmal site, aneurysm in left circumflex artery (LCX) and mild luminal irregularities in distal left anterior descending (figure 2A). $\mathrm{He}$ underwent mechanical thrombectomy with restoration of flow from TIMI 0 to TIMI 1 (figure 2B). After the procedure patient was started on aspirin $81 \mathrm{mg}$ q.d., prasugrel $10 \mathrm{mg}$ q.d. and rivaroxaban $2.5 \mathrm{mg}$ bid.

Coronary artery aneurysm (CAA) is the localised dilatation of a coronary artery with diameter $>1.5$ times diameter of adjacent normal segment. Its incidence is reported as $0.3 \%-5.3 \%$ with mean incidence of $1.65 \%$ from pooled analysis. ${ }^{1}$ Men are affected more predominantly than women. Atherosclerotic coronary artery disease is the most common cause of CAA in adult population whereas Kawasaki disease triumphs in children. Atherosclerosis is usually associated with multi-vessel coronary aneurysms as seen in our patient involving RCA and LCX. ${ }^{2}$ Other aetiologies include genetic causes, inflammatory, connective tissue disorders and infectious diseases. CAA is usually an incidental finding but can be complicated by thrombosis and embolism. The aneurysmal dilatation provides a nidus for acute thrombus formation which can present as STEMI. Thrombus formation is favoured at aneurysmal site due to more sluggish flow through a dilated vessel. Patients usually present with angina, ischaemia or myocardial infarction. Coronary angiography is valuable diagnostic tool for CAA. Intravascular ultrasound can aid in differentiating true versus pseudo-aneurysms and helps in determination of luminal composition of the aneurysm. ${ }^{3}$ There is lack of consensus in the optimal management of CAA. Guideline-directed medical management is preferred in the setting of atherosclerotic coronary artery disease. Antiplatelet

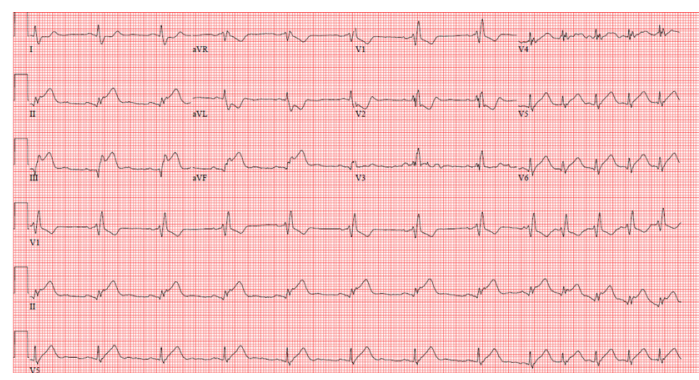

Figure 1 ECG showing ST elevations in the leads II, III and aVF.

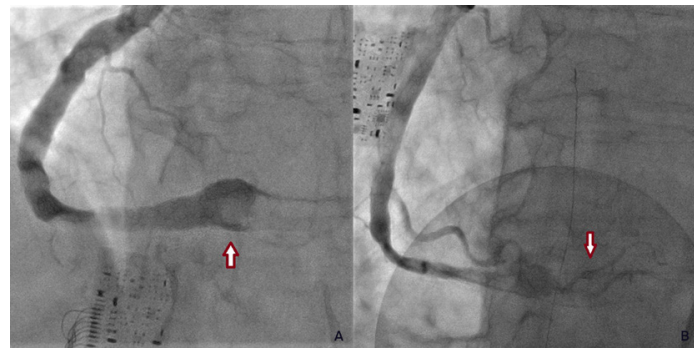

Figure 2 A: showing 100\% occlusion of right coronary artery (RCA) with thrombosis at the site of coronary artery aneurysm. B: showing improvement in the flow in RCA after mechanical thrombectomy.

medications with anticoagulants should be considered if thrombosis/embolism is a concern, as noted in our case. ${ }^{4}$ Bleeding risk of the patient should be taken into consideration before combining dual antiplatelet therapy (DAPT) and anticoagulation. As shown in the PIONEER AF-PCI trial, rivaroxaban has been shown to have less bleeding risk than vitamin $\mathrm{K}$ antagonist when used in combination with DAPT. Inflammatory cytokines and matrix metalloproteinase have been linked to CAA; therefore, statins have been hypothesised to play an essential role in management. ${ }^{5}$ Intravenous immunoglobulin is the mainstay of therapy for Kawasaki disease associated CAA. Invasive management involves percutaneous intervention which includes covered stents, coil insertion but is usually reserved for smaller aneurysms. Surgical techniques which include aneurysmal resection, aneurysmal ligation, aneurysmectomy with or without bypass grafting are reserved for saccular aneurysms or larger aneurysms $(>10 \mathrm{~mm})$ which are at increased risk for rupture. ${ }^{6}$

\section{Learning points}

- Atherosclerosis can cause multi-vessel coronary artery aneurysms. Right coronary artery is predominantly affected in $40 \%-70 \%$ cases.

- There is lack of consensus regarding the optimal management of coronary artery aneurysm. Guideline-directed medical therapy is preferred.

- Dual antiplatelet therapy with anticoagulation should be considered if thrombosis/embolism is a concern as noted in our case.

Contributors FS: initial draft. AB: editing and reviewing. JKK: final review and procedure.

Funding The authors have not declared a specific grant for this research from any funding agency in the public, commercial or not-for-profit sectors.

Competing interests None declared.

Patient consent for publication Obtained. 
Images in...

Provenance and peer review Not commissioned; externally peer reviewed.

\section{REFERENCES}

1 Hartnell GG, Parnell BM, Pridie RB. Coronary artery ectasia. Its prevalence and clinical significance in 4993 patients. Br Heart J 1985;54:392-5.

2 Cohen P, O'Gara PT. Coronary artery aneurysms: a review of the natural history, pathophysiology, and management. Cardiol Rev 2008;16:301-4.
3 Ge J, Liu F, Kearney P, et al. Intravascular ultrasound approach to the diagnosis of coronary artery aneurysms. Am Heart J 1995;130:765-71.

4 Demopoulos VP, Olympios CD, Fakiolas $\mathrm{CN}$, et al. The natural history of aneurysmal coronary artery disease. Heart 1997:78:136-41.

5 Nichols L, Lagana S, Parwani A. Coronary artery aneurysm: a review and hypothesis regarding etiology. Arch Pathol Lab Med 2008;132:823-8.

6 Harandi S, Johnston SB, Wood RE, et al. Operative therapy of coronary arterial aneurysm. Am J Cardiol 1999;83:1290-3.

Copyright 2019 BMJ Publishing Group. All rights reserved. For permission to reuse any of this content visit https://www.bmj.com/company/products-services/rights-and-licensing/permissions/

BMJ Case Report Fellows may re-use this article for personal use and teaching without any further permission.

Become a Fellow of BMJ Case Reports today and you can:

- Submit as many cases as you like

Enjoy fast sympathetic peer review and rapid publication of accepted articles

Access all the published articles

Re-use any of the published material for personal use and teaching without further permission

\section{Customer Service}

If you have any further queries about your subscription, please contact our customer services team on +44 (0) 2071111105 or via email at support@bmj.com.

Visit casereports.bmj.com for more articles like this and to become a Fellow 